\title{
SIKAP PROFESIONAL MAHASISWA BOGA PTBB FT UNY SEBAGAI PERWUJUDAN PROFESI TENAGA KERJA BOGA
}

\author{
Siti Hamidah \\ Fakultas Teknik Universitas Negeri Yogyakarta \\ Email: hamidah_siti66@yahoo.com
}

\begin{abstract}
Abstrak: Sikap Profesional Mahasiswa Boga PTBB FT UNY sebagai Perwujudan Profesi Tenaga Kerja Boga. Penelitian ini bertujuan untuk mendiskripsikan keadaan sikap profesional mahasiswa Boga dan aspek sikap profesional mahasiswa Boga. Jenis penelitian ini adalah survei. Penentuan sampel dengan teknik purposive sampling, yaitu mahasiswa Boga baik Program Strata 1 dan diploma 3 yang telah menempuh mata kuliah praktek industri. Data dikumpulkan melalui instrumen yang dikembangkan berdasarkan aspek sikap profesional. Data dianalisis secara diskriptif kuantitatif dengan kategori, tinggi, sedang dan kurang. Hasil penelitian menunjukkan bahwa keadaan sikap profesional mahasiswa boga dalam kategori sedang. Aspek sikap profesional yang masih perlu ditingkatkan adalah kebutuhan belajar sepanjang waktu serta kebutuhan kreatif dan inovatif.
\end{abstract}

Kata kunci: mahasiswa boga, sikap profesional

\begin{abstract}
Professional Attitude of Culinary Students in PTBB UNY as the Embodiment of Labor Culinary Profession. This study was aimed at describing the professional attitude of cullinary students and the aspects of the professional attitude of cullinary students. This research is survey research. The sample that was chosen through purposive sampling, were: both $S 1$ and D3 cullinary students who had taken industrial practice course. The data were collected through instrument that was developed based on the professional attitude aspects. Then the data were analyzed using quantitative descriptive with categories: high, medium, and less. The results show that 1) the professional attitude cullinary of most students are in medium category, 2) the professional attitude aspects that still need to be improved are the need of longlife learning, and the need of creativity and innovative.
\end{abstract}

Keywords: cullinary student, professional attitude

\section{PENDAHULUAN}

Tuntutan SDM profesional semakin mengemuka. Hal ini terkait dengan adanya persaingan global yang semakin ketat dan tajam. Keadaan ini semakin terlihat dengan munculnya sejumlah kompetensi yang menjadi kesepakatan APEC di Xi'an China yang memiliki nilai penting bagi mahasiswa ketika mereka memasuki dunia kerja, meliputi: lifelong learning, problem solving, self management dan team work. Oleh karenanya SDM yang profesional adalah yang memiliki keunggulan kompetetif dan komparasi.

Kebutuhan SDM profesional menjadi lebih penting terutama dikaitkan dengan akan diberlakukannya Asean Economic Community (AEC) 2015. Menteri Koordinasi Bidang Perekonomian Hatta Rajasa mengakui, masih banyak 
pekerjaan rumah yang harus ditangani agar bangsa Indonesia siap bersaing di pasar bebas tahun 2015. Pekerjaan rumah tersebut meliputi: ketahanan pangan, ketahanan energi, ketahanan industri, current account, meningkatkan SDM, pemerataan pembangunan, pengurangan kemiskinan, UKM, integrasi usaha besar dan UKM linkage dengan financing (Rajasa, 2013). Permasalahan tersebut bila diteliti terletak pada keadaan SDM yang masih belum memenuhi kebutuhan pembangunan.

Dalam bidang SDM masih banyak dibutuhkan tenaga terampil ataupun tenaga profesional. Rendahnya tenaga terampil akan menjadi beban ekonomi Negara karena sebagian dari mereka menjadi penganggur. Tenaga profesional menunjukkan orang yang memiliki keahlian sesuai dengan bidangnya, menunjukkan sikap dan perilaku sebagai ciri profesinya. Seorang profesional lahir karena pendidikan yang mampu menjamin dikuasainya sejumlah kompetensi kunci yang diperlukan untuk bersaing dipasar bebas.

Pendidikan Boga mendidik SDM men-jadi lulusan yang profesional. Namun dengan melihat kenyataan tersebut di atas, memunculkan berbagai pertanyaan: apakah pembelajaran selama ini sudah mampu membekali sejumlah kompetensi yang diperlukan untuk bekerja?, apakah dalam pembelajaran sudah melatihkan standar perilaku profesional? Apakah para mahasiswa telah bangga dengan profesinya?

Mahasiswa Boga yang mengambil pendidikan boga maupun nonkependidikan jumlahnya semakin banyak. Dalam kenyataannya kesadaran akan profesi sebagai tenaga kependidikan ataupun seorang wirausaha boga dirasa masih kurang. Hal ini terjadi karena sebagian besar image mahasiswa masuk di bidang
Boga ingin menjadi seorang ahli masak seperti yang diidolakan. Namun perilaku yang menjadi ciri profesi pilihan tersebut belum difahami dengan benar. Demikian halnya dalam keseharian sebagian besar mahasiswa belum menunjukkan perilaku untuk mendapatkan pengetahuan, sikap ataupun skills sebagai modal profesinya. Apalagi meningkatkan dan memperbaiki kualitas diri, agar semakin mantap dengan profesinya.

Walaupun cita-cita sebagian be-sar mahasiswa tidak salah karena tujuan kurikulum Boga UNY adalah menjadikan lulusan sebagai tenaga pendidik dan wirausaha boga. Artinya lulusan kependidikan bisa menjadi ahli wirausaha boga demikian sebaliknya lulusan D3 nonkependidikan dapat menjadi tenaga kependidikan manakala mengambil program kelanjutan studi S1 kependidikan.

Yang penting adalah sikap dan perilaku profesinya harus sudah nampak selama pendidikan. Oleh karena itu diperlukan penelitian untuk mengungkap seperti apakah sikap profesional mahasiswa Boga. Hal ini penting karena lulusan boga akan berhadapan dengan masa-masa sulit dengan masuknya tenaga kerja asing yang dapat bekerja di sektor jasa ataupun mungkin ke pendidikan. Manakala mahasiswa telah menyadari pentingnya sikap dan perilaku profesional sebagai wujud jati diri profesinya, maka ada usaha mahasiswa untuk mendalami pengetahuan, skills dan sikap sebagai seorang yang pofesional. Hal ini ditunjukkan oleh tampilan fisik sebagai cerminan pribadinya, mempunyai pribadi yang menyenangkan, dan mampu membina hubungan kerja ataupun tim belajar yang solid dan menyenangkan.

Dalam pembelajaran sikap adalah sesuatu yang penting. Ketika seorang mahasiswa mempunyai sikap negatif maka akan mempersulit dirinya saat 
berinteraksi di dalam Kelas Ataupun untuk pengembangan diri. Mahasiswa yang memiliki sikap negatif akan menunjukkan perilaku sering tidak masuk, bekerja lambat saat praktek, ataupun tidak produktif, dan biasanya berhubungan dengan disiplin kerja. Oleh karenanya dosen sebagai pengelola pembelajaran harus dapat mengelola sikap mahasiswa dengan menunjukkan perilaku yang mampu memberi kenyamanan belajar dan memberi apresiasi atas prestasi kerjanya seperti apapun hasilnya. Sikap dapat mempengaruhi emosi dan perilaku seseorang, karenanya dosen harus dapat memberikan pemahaman yang benar tentang perilaku sebagai mahasiswa, menumbukan rasa bangga dan mendorong untuk berperilaku yang positif.

Sikap menunjuk pada kecenderungan belajar untuk merespon pada obyek be-rupa orang, tempat ataupun sasaran sikap dengan cara memberi respon negatif ataupun positif (Dennis, 1980: 574). Sikap merupakan bentuk hasil belajar masa lalu, dan memprediksi atau mengarahkan tindakan di masa depan. Oleh karenanya sikap dapat terbentuk pada masa lalu ataupun saat ini, dan dapat berubah karena situasi sosial. Dengan demikian sikap terbentuk karena interaksi sese-orang dengan lingkungan sosialnya. Sekolah merupakan masyarakat belajar atau lingkungan sosial yang dapat mempengaruhi mahasiswa dan kesediaan dirinya memberi respon positif terhadap obyek sikap. Harapannya interaksi antara mahasiswa dengan lingkungan sosial akan melahirkan sikap positif terhadap objek sikap.

Sikap merupakan kondisi mental yang mempengaruhi cara pandang terhadap sesuatu yang diyakini (Newstrom. 2007: 203). Sikap menurut Allport seperti yang dikutip oleh Mar'at (1982: 9): a mental and neural state of readiness, organized through experince, exerting a directive or dynamic influence up on the individual's response to all objects and situations with which it is related.

Professionalism does not mean wearing a suit or carrying a briefcase; rather, it means conducting oneself with responsibility, integrity, accountability, and excellence. It means communicating effectively and appropriately and always finding a way to be productive. (Anonim, tanpa tahun). Dengan kata lain profesionalisme bukan tercermin dari tampilan fisik semata seperti pakaian, dandanan wajah namun lebih pada perilaku kerja yang penuh tanggung jawab, integritas, akuntabilitas dan keunggulan. Mampu melakukan komunikasi yang efektif dan tepat saat bekerja, dan memiliki cara-cara untuk bekerja secara produktif. Dengan sendirinya profesionalisme menunjukkan kemahiran, kepakaran, ataupun kualitas perilaku seorang profesional.

Lulusan Boga adalah pekerja vokasi. Oleh karena itu, sikap profesi guru sekaligus mencerminkan sikap profesi bukan guru. Bidang boga yang dipelajari memiliki fungsi untuk membekali kedua profesi tersebut. Hal ini dimungkinkan karena kurikulum yang dikembangkan Prodi Teknik Boga dan Prodi Pendidikan Teknik Boga mewadahi kedua kepentingan tersebut. Namun bisa jadi setiap mahasiswa memiliki kepentingan yang beragam terkait dengan fokus sikap profesional mereka. Hal ini terjadi karena sikap adalah personality, dan personality ditentukan oleh cara pandang masingmasing orang terhadap obyek sikap. Selain itu juga ditentukan seberapa kuat stimulus yang diterima oleh mahasiswa terkait dengan lingkungan belajar, teman, atau informasi dosen tentang masa 
depan lulusan. Pesan berperan sebagai bentuk persuasi. Seberapa besar kekuatan pesan dan keinginan untuk memproses pesan sebagai bentuk meneguhkan sikap atau merubah sikap ditentukan oleh mahasiswa sendiri

Beberapa sikap profesional yang penting adalah: rasa bangga terhadap pekerjaan, kerja keras, bekerja sama dalam tim, kebutuhan belajar sepanjang waktu, mengutamakan mutu dan kualitas kerja yang terstandar, kebutuhan bekerja efektif, efisien dan produktif, kebutuhan kreatif dan inovasi, memiliki kekuatan untuk berubah, dan komunikasi yang efektif (Gisslen, 2007). Mencermati ke-9 sikap profesional tersebut, dapat saja setiap mahasiswa mempunyai fokus dan kekuatan yang berbeda akan sikap profesional mereka.

\section{METODE}

Penelitian ini menggunakan pendekatan diskriptif kuantitatif dengan metode survei. Populasi penelitian ini adalah semua mahasiswa Program S1 Pendidikan Teknik Boga (PTB) dan D3 Teknik Boga (TB). Sebagai sampel ditentukan mahasiswa yang telah mengalami praktek paling tidak 20 sks atau Semester 4. Untuk itu, penelitian ini mengambil Semester 5 Program S1 PTB dan Program D3 TB dengan pertimbangan bahwa mahasiswa tersebut telah selesai Praktek Industri, sehingga sudah memiliki pengalaman kerja yang profesional.

Data dikumpulkan melalui angket sikap profesional dengan skala likert, setelah sebelumnya dilakukan uji tingkat validitas konstruk. Pengujian tingkat validitas menggunakan ekspert jugment yaitu seminar instrumen penelitian. Masukan dari hasil seminar ini akan dipergunakan untuk perbaikan. Data dianalisis secara diskriptif kuantitatif dengan katagori tinggi, sedang dan kurang. HASIL DAN PEMBAHASAN

Hasil penelitian tentang sikap profesional mahasiswa Program S1 PTB Kelas A dan Kelas D serta Program D3 TB secara berturut-turut disajikan sebagai berikut.

\section{Keadaan Sikap Profesional Mahasiswa}

Sikap profesional mahasiswa Program S1 PTB dan D3 TB menunjuk pada perilaku yang terkait dengan rasa bangga terhadap pekerjaan, mengutamakan mutu dan kualitas kerja yang terstandar, kerja keras, bekerja sama dalam tim, kebutuhan belajar sepanjang waktu, ke-butuhan bekerja yang efektif, efisien dan produktif, kebutuhan kreatif dan inovatif, memiliki kekuatan untuk berubah dan komunikasi yang efektif.

Berdasarkan keadaan rerata perolehan nilai maka dibuat tiga kategori keadaan sikap yang menggambarkan kategori tinggi, sedang dan kurang. Gambaran sikap profesional secara berturut-turut disajikan pada Tabel 1.

Tabel 1 menunjukkan bahwa sebagian besar mahasiswa S1 Kelas A memiliki sikap profesional pada katagori sedang yaitu $58 \%$, hanya 4 mahasiswa atau $10 \%$ yang menguasai sikap profesional dalam kategori baik. Keadaan ini menunjukkan bahwa mahasiswa S1 Kelas A telah berhasil mengembangkan sikap profesional yang baik, sejalan dengan lamanya studi di Prodi PTB ini. Harapannya ketika lulus kondisi keprofesionalan menjadi semakin baik.

Gambaran sikap profesional mahasiswa S1 Kelas D disajikan pada Tabel 2. Tabel 2 menunjukkan bahwa sebagian besar mahasiswa S1 Kelas D memiliki sikap profesional pada katagori rendah, hanya 2 mahasiswa yang menguasai sikap profesional dalam kategori baik. 
Tabel 1. Keadaan Sikap Profesional Mahasiswa S1 Kelas A

\begin{tabular}{ccccc}
\hline No & Interval Kelas & Klasifikasi & Frekuensi & Persentase \\
\hline 1 & $2,7-3,05$ & kurang & 13 & $32 \%$ \\
2 & $3,1-3,45$ & sedang & 23 & $58 \%$ \\
3 & $3,5-3,85$ & tinggi & 4 & $10 \%$ \\
\hline & Jumlah & & 40 & $100 \%$ \\
\hline
\end{tabular}

Tabel 2. Keadaan Sikap Profesional Mahasiswa S1 Kelas D

\begin{tabular}{ccccc}
\hline No & Interval Kelas & Klasifikasi & Frekuensi & Persentase \\
\hline 1 & $2,7-3,05$ & kurang & 26 & $64 \%$ \\
2 & $3,1-3,45$ & sedang & 13 & $32 \%$ \\
3 & $3,5-3,85$ & tinggi & 2 & $4 \%$ \\
\hline & Jumlah & & 41 & $100 \%$ \\
\hline
\end{tabular}

Gambaran sikap profesional mahasiswa program D3 disajikan pada Tabel 3. Tabel 3 menunjukkan bahwa sebagian besar mahasiswa D3 memiliki sikap profesional pada katagori kurang yaitu $72 \%$, hanya 1 mahasiswa atau $3 \%$ yang menguasai sikap profesional dalam kategori baik. Keadaan ini menunjukkan bahwa mahasiswa D3 belum berhasil mengembangkan sikap profesional yang baik. Oleh karena itu, mereka perlu dilatih lebih keras dan lebih sering.

Secara keseluruhan keadaan sikap profesional para mahasiswa Program S1 maupun D3 Program Studi PTB dan TB terlihat perbedaannya. Gambaran tersebut tersaji dalam Tabel 4.

Tabel 3. Keadaan Sikap Profesional Mahasiswa Program D3

\begin{tabular}{ccccc}
\hline No & Interval Kelas & Klasifikasi & Frekuensi & Persen \\
\hline 1 & $2,7-3,05$ & kurang & 20 & $72 \%$ \\
2 & $3,1-3,45$ & sedang & 7 & $25 \%$ \\
3 & $3,5-3,85$ & tinggi & 1 & $3 \%$ \\
\hline jumlah & & 28 & $100 \%$ \\
\hline
\end{tabular}

Tabel 4. Keadaan Sikap Profesional Mahasiswa Program PTB dan TB

\begin{tabular}{cccccc}
\hline No & Interval Kelas & Klasifikasi & S1 A & S1 D & D3 \\
\hline 1 & $2,7-3,05$ & kurang & $32 \%$ & $64 \%$ & $72 \%$ \\
2 & $3,1-3,45$ & sedang & $58 \%$ & $32 \%$ & $25 \%$ \\
3 & $3,5-3,85$ & baik & $10 \%$ & $4 \%$ & $3 \%$ \\
\hline \multicolumn{7}{r}{ Jumlah } & & $100 \%$ & $100 \%$ & $100 \%$ \\
\hline
\end{tabular}


Tabel 4 menunjukkan bahwa keadaan sikap profesional S1 A lebih baik dari S1 D dan D3. Secara berurutan yang terbaik kondisi sikap profesional mulai dari program S1 A, S1 D dan terakhir Program D3. Bisa dilihat pada Gambar 1.

Keadaan ini memberi implikasi pada perlunya pembelajaran sikap profesional yang terus melekat pada setiap pembelajaran terutama pada Program S1 Kelas D dan D3. Walaupun kondisi keadaan sikap profesional setiap angkatan bisa saja berbeda tetapi program pengintegrasian pembelajaran sikap profesional tetap harus mendapat prioritas. Mahasiswa harus memiliki sikap profesional yang baik, karena sikap adalah hal yang penting untuk meraih sukses di masa depan.

Perbandingan rerata untuk setiap aspek secara terperinci adalah sebagai berikut. Keadaan variasi aspek sikap profesional mahasiswa disajikan pada Gambar 2 dan Gambar 3.
Gambar 2 menunjukkan bahwa hampir semua aspek sikap profesional telah mencapai tahap di atas angka tiga. Adapun aspek yang mendekati angka tiga, hanya kebutuhan belajar sepanjang waktu, kebutuhan kreatif dan inovatif. Dengan demikian dapat dinyatakan bahwa Program S1 Kelas A telah mampu menunjukkan perilaku sebagai cerminan sikap profesional.

Gambar 3 menunjukkan bahwa belum semua aspek sikap profesional mencapai tahap di atas angka tiga. Adapun aspek yang mendekati tiga ada pada aspek mengutamakan mutu dan kualitas kerja yang terstandar, kebutuhan belajar sepanjang waktu, kebutuhan kreatif dan inovatif. Dengan demikian dapat dinyatakan bahwa Program S1 Kelas D masih memerlukan motivasi agar dapat menunjukkan perilaku sebagai cerminan sikap profesional secara lebih baik.

Gambar 4 menyajikan keadaan variasi rerata aspek sikap profesional Program D3.

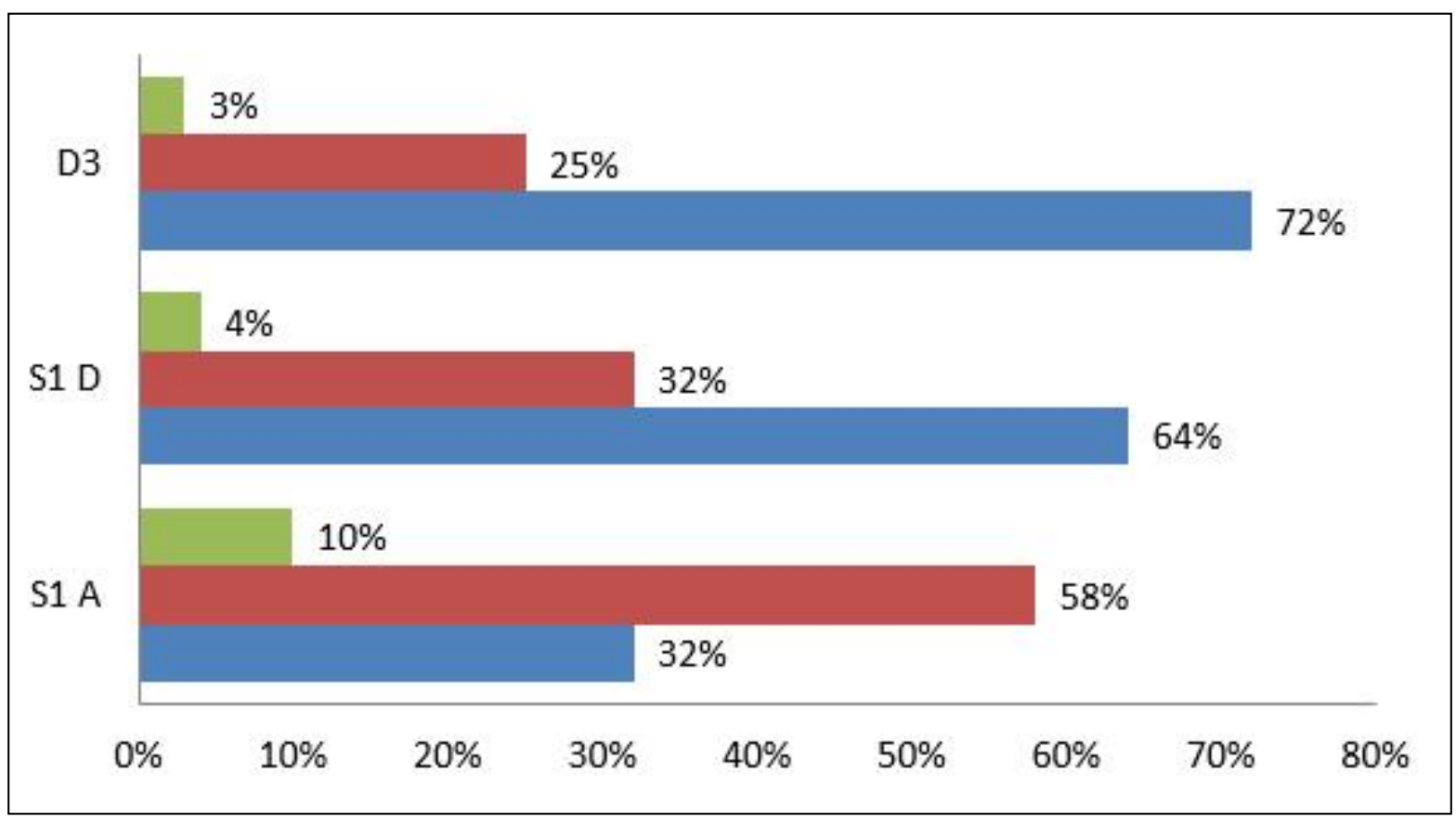

Gambar 1. Keadaan Sikap Profesional Mahasiswa PTB dan TB 


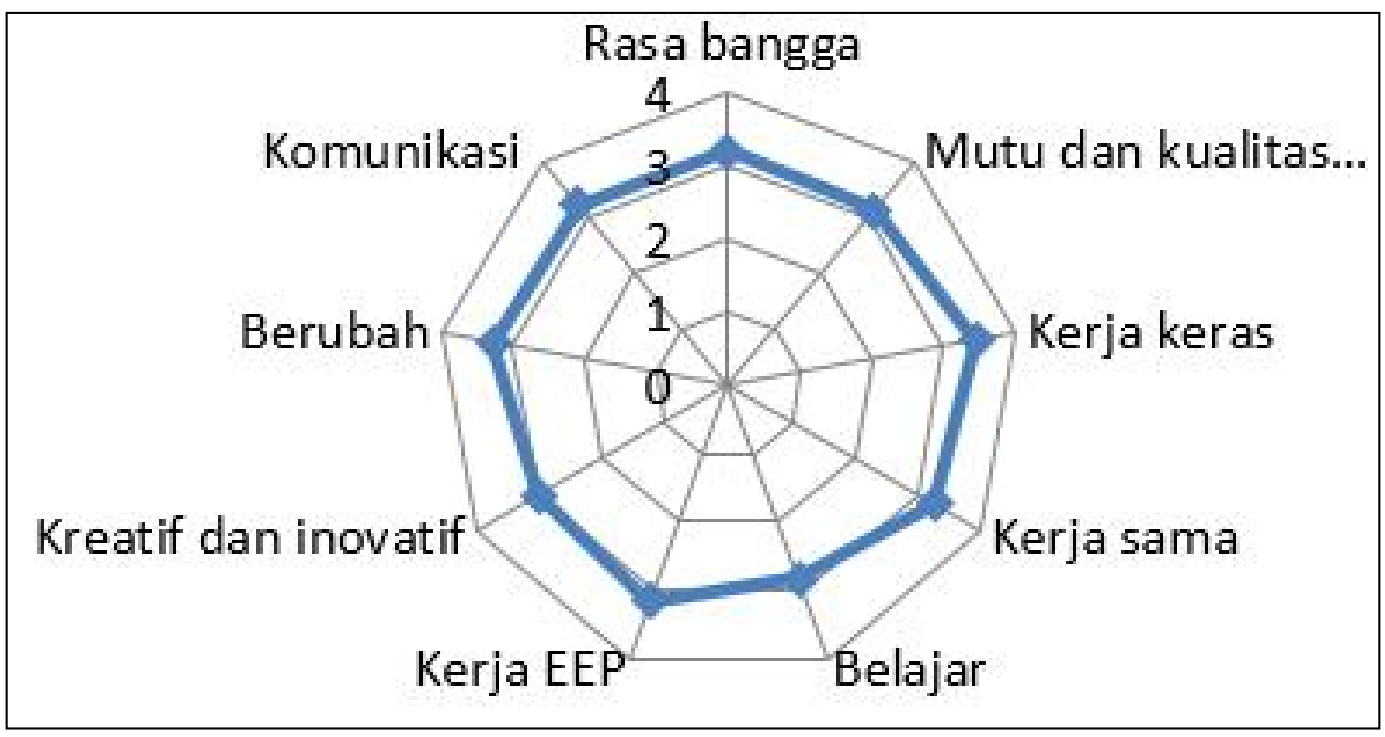

Gambar 2. Keadaan Variasi Aspek Sikap Profesional Program S1 Kelas A

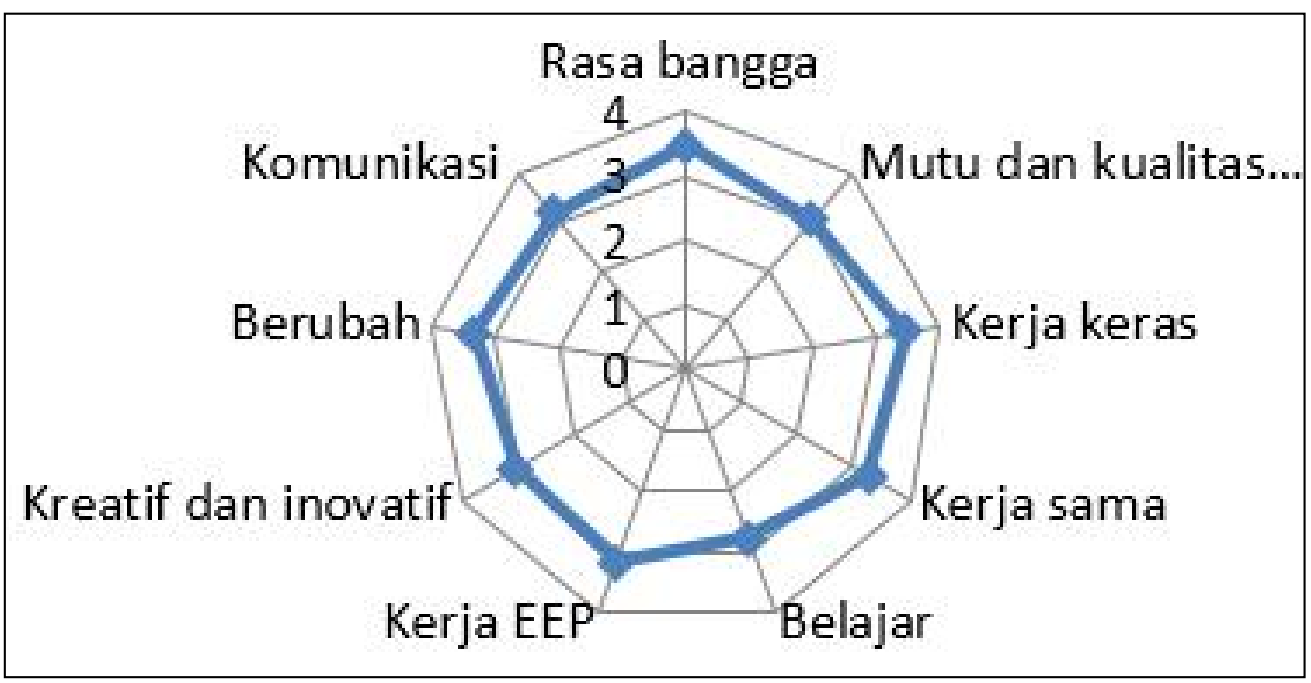

Gambar 3. Keadaan Rerata Variasi Aspek Sikap Profesional Program S1 Kelas D

Dari Gambar 3 terlihat bahwa masih cukup banyak ditemukan aspek sikap profesional belum mencapai angka tiga. Adapun aspek yang masih perlu ditingkatkan adalah rasa bangga terhadap pekerjaan, mengutamakan mutu dan kualitas kerja yang terstandar, kebutuhan belajar sepanjang waktu, kebutuhan bekerja yang efektif, efisien dan produktif, kebutuhan kreatif dan inovatif. Dengan kata lain dari sembilan aspek yang harus dikuasai hanya ada empat aspek yang dikuasai lebih baik yaitu kerja keras, bekerja sama dalam tim, memiliki kekuatan untuk berubah dan komunikasi yang efektif.

Urutan pencapaian aspek untuk ketiga program disajikan pada Tabel 5. Dengan menggunakan kriteria kategori: 1) 2,7-3,05 adalah kurang; 2) 3,1-3,45 adalah sedang; dan 3) 3,5-3,85 adalah 


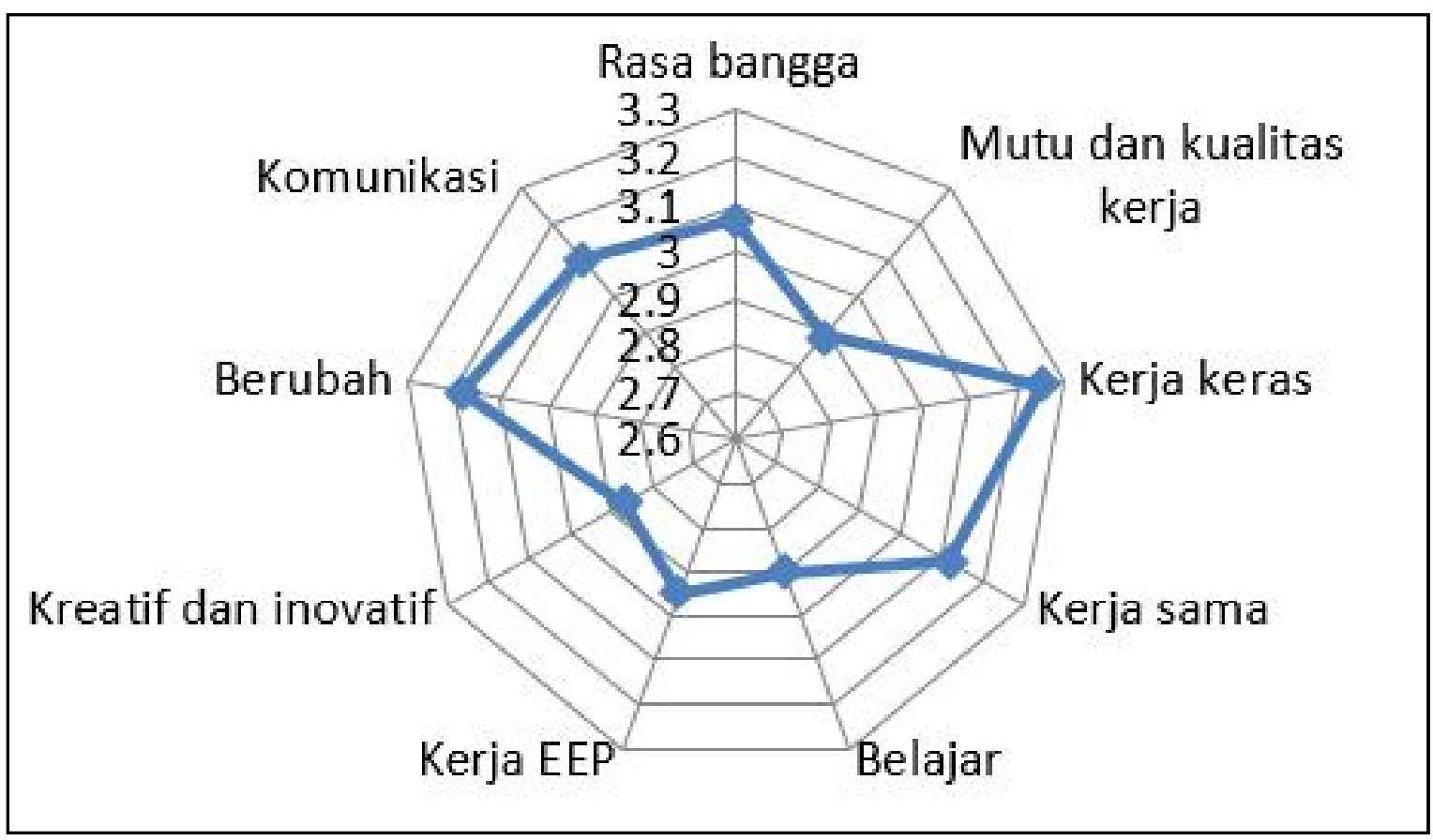

Gambar 4. Keadaan Variasi Rerata Aspek Sikap Profesional Program D3

Tabel 5. Keadaan Rerata Setiap Aspek Sikap Profesional Mahasiswa PTB dan TB

\begin{tabular}{clcccccc}
\hline No & \multicolumn{1}{c}{ Aspek } & S1 A & Kategori & S1 D & Kategori & D3 & Kategori \\
\hline 1 & Belajar & 2,82 & kurang & 2,76 & kurang & 2,90 & kurang \\
2 & Kreatif \& inovatif & 3,02 & kurang & 3,05 & kurang & 2,87 & kurang \\
3 & Mutu \& kualitas & 3,12 & sedang & 3,02 & kurang & 2,89 & kurang \\
& kerja & & & & & & \\
4 & Kerja EEP & 3,15 & sedang & 3,18 & sedang & 2,95 & kurang \\
5 & Rasa bangga & 3,21 & sedang & 3,49 & sedang & 3,07 & kurang \\
6 & Kerja keras & 3,45 & sedang & 3,46 & sedang & 3,25 & sedang \\
7 & Kerja sama & 3,27 & sedang & 3,26 & sedang & 3,12 & sedang \\
8 & Komunikasi & 3,22 & sedang & 3,18 & sedang & 3,1 & sedang \\
9 & Berubah & 3,27 & sedang & 3,33 & sedang & 3,18 & sedang \\
\hline
\end{tabular}

tinggi maka terlihat bahwa setiap kelas kurang bervariasi keadaannya. Demikian halnya bila dibandingkan antarkelas maka terlihat bahwa kelas Program S1 A lebih baik. Artinya yang berada pada kategori kurang adalah kebutuhan belajar sepanjang waktu serta kebutuhan kreatif dan inovatif. Kedua kategori tersebut juga muncul pada Program S1 D dan Program D3.

Bila dilihat untuk setiap kelas, maka ada beberapa sikap profesional yang 
masih perlu ditingkatkan. Pada program D3 ada 5 sikap profesional yaitu: 1) Rasa bangga terhadap pekerjaan, 2) mengutamakan mutu dan kualitas kerja yang terstandar, 3) kebutuhan belajar, 4) kebutuhan bekerja yang efektif, efisien dan produktif, 5) kebutuhan kreatif dan inovatif. Pada Program S1 Kelas D ada 3 sikap profesional yaitu: 1) mengutamakan mutu dan kualitas kerja yang terstandar, 2) kebutuhan belajar, 3) kebutuhan kreatif dan inovatif.

Gambaran sikap profesional mahasiswa Boga Pogram S1 PTB dan Program D3 TB sebagian besar berada pada di ranah sedang. Demikian halnya untuk setiap aspek sikap profesional belum semua berada pada kategori yang memuaskan, antara lain Kebutuhan belajar, kebutuhan bekerja yang efektif, efisien dan produktif, dan mengutamakan mutu dan kualitas kerja yang terstandar. Bila dilihat dari keadaan setiap kelas maka Program S1 Kelas A lebih unggul dibandingkan dengan Program S1 Kelas D dan Program D3. Hal ini bisa terjadi mungkin didasarkan keadaan kelas yang terlihat lebih baik dibanding dengan Kelas D dan D3.

Apabila dikaitkan dengan pendapat Dennis (1988), bahwa sikap merupakan bentuk hasil belajar masa lalu, dan memprediksi atau mengarahkan tindakan di masa depan. Oleh karenanya sikap dapat terbentuk pada masa lalu ataupun saat ini, dan dapat berubah karena situasi sosial. Dapat diduga variasi keadaan sikap profesional yang ditunjukkan oleh masing-masing kelas merupakan akibat dari hasil pembelajaran yang diperoleh saat di SMU/SMK yang terus dibawa saat mahasiswa dan ditumbuh kembangkan sampai saat ini (Semester 5).

Sikap merupakan kondisi mental yang mempengaruhi cara pandang terhadap sesuatu yang diyakini (Newstrom, 2007: 203). Sikap menurut Allport seperti yang dikutip oleh Mar'at (1982: 9): “a mental and neural state of readiness, organized through experince, exerting a directive or dynamic influence up on the individual's response to all objects and situations with which it is related". Artinya manakala sikap profesional ini telah menjadi keyakinan para mahasiswa maka dengan sendirinya akan mempengaruhi perilakunya.

Pembelajaran baik teori maupun praktek harus mampu menumbuhkan sikap profesional secara berkelanjutan. Rasa bangga pada pekerjaan akan mendorong mahasiswa bekerja semakin baik dan semakin mumpuni dan ahli. Mahasiswa akan bekerja dengan dasar pengetahuan yang benar dengan diikuti dukungan skills yang memungkinkan bekerja dengan cepat, tepat, tertib, penuh kreasi dan inovasi.

Demikian halnya bahwa sikap profesional itu terbentuk karena interaksi mahasiswa Boga dengan lingkungan sosialnya. Sekolah merupakan masyarakat belajar atau lingkungan sosial yang dapat mempengaruhi mahasiswa dan kesediaan dirinya memberi respon positif terhadap obyek sikap. Harapannya interaksi antara mahasiswa dengan lingkungan sosial akan melahirkan sikap positif terhadap obyek sikap. Pernyataan ini dapat menjelaskan mengapa penelitian ini mengambil sampel mahasiswa yang telah mengambil praktek industri, harapannya mahasiswa memiliki sikap profesional yang baik. Namun kenyataannya sikap profesional mahasiswa belum memenuhi harapan. Oleh karena itu perlu ada penelitian yang lebih mendalam agar dapat terungkap keadaan sikap profesional yang belum maksimal meskipun para mahasiswa ini telah berada di Semester 5 . 


\section{SIMPULAN}

Berdasarkan kajian hasil penelitian tentang sikap profesional mahasiswa Boga sebagai perwujudan profesi tenaga kerja boga maka dapat disimpulkan sebagai berikut. Keadaan sikap profesional boga meliputi: Program S1 Kelas A menunjukkan bahwa sebagian besar mahasiswa Program S1 Kelas A sikap profesional pada katagori sedang yaitu 58\%, hanya 4 mahasiswa atau $10 \%$ yang menguasai sikap profesional dalam kategori baik. Program S1 Kelas D menunjukkan sebagian besar mahasiswa Program S1 Kelas D memiliki sikap profesional pada katagori kurang atau $64 \%$, hanya $2(4 \%)$ mahasiswa yang menguasai sikap profesional dalam kategori baik. Program D3 menunjukkan bahwa sebagian besar mahasiswa Program D3 menunjukkan sikap profesional pada katagori kurang yaitu $72 \%$, hanya 1 mahasiswa atau $3 \%$ yang menguasai sikap profesional dalam kategori baik. Bila dilihat variasi aspek sikap profesional dimasingmasing program, menunjukkan terdapat kurang bervariasi. Kondisi aspek sikap profesional yang terbaik berturut-turut Program S1 Kelas A, Program S1 Kelas D dan terakhir adalah Program D3. Aspek yang harus mendapat perhatian adalah kemampuan untuk selalu belajar dan kemampuan akan kreatif dan inovatif.

Sehubungan hasil penelitian di atas maka ada beberapa saran terkait dengan pembelajaran sebagai berikut. Perlu dikembangkan pembelajaran yang lebih menguatkan perilaku profesional yang terintegrasi. Kesepakatan antardosen akan saling menguatkan sikap profesional secara berkelanjutan. Jurusan perlu mendorong dosen-dosen mencoba pembelajaran terintegrasi untuk menumbuhkan sikap profesional secara berkelanjutan. Perlu pembelajaran yang memberi ruang munculnya kemampuan belajar sepanjang hayat yang tidak dibatasi oleh ruang dan waktu. Hal ini akan memberi arti bagi mahasiswa dalam memanfaatkan sumber belajar yang bervariasi, pengalaman kerja saat praktek industri sebagai bagian dari peneguhan sikap profesional. Demikian halnya pembelajaran yang berbasis pada munculnya kerja kreatif dan pemecahan masalah secara kreatif untuk memunculkan hasil kerja inovatif sebagai bukti sikap profesional.

\section{DAFTAR PUSTAKA}

Anonim. tth. Professionalism, dari https:// www.dol.gov/odep/topics/youth/ softskills/. Diunduh 26 Februari 2014.

Dennis, C. 1980. Introduction to Psychology Exploration and Application. St Paul: West Publishing Company.

Gisslen, W. 2007. Professsional Cooking. Hoboken, NJ: John Wiley \& Sons Inc.

Mar'at. 1991. Sikap Manusia Perubahan Serta Pengukurannya. Yogyakarta: Ghalia Indonesia.

Newstrom, J,W. 2007. Organization Behavior. Human Behavior at Work. Singapura: McGraw-Hill Education.

Rajasa, H. 2013. "Hadapi Perdagangan Bebas, Indonesia Punya Banyak PR", dari http://economy.okezone.com/ $\mathrm{read} / 2013 / 11 / 14 / 320 / 896924 /$. Diunduh 26 Februari 2014. 